\title{
Out On a Limb - and Thriving
}

\author{
Robert Seliger \\ CEO, Sentillion, Inc.
}

$T$ his issue of the New England Journal of Entrepreneurship features Robert Seliger, the 42year-old CEO of Sentillion, a fledgling organization headquartered in Andover, Massachusetts, that has developed the means of coordinating and integrating complex applications in the medical technology field. Seliger graduated from Cornell University as an engineering major. holds a master's degree from the Massachusetts Institute of Technology, and was employed by Hewlett Packard where he moved up the ranks over 18 years to principal architect and senior manager of a product development team in clinical information systems.

NEJE: Our first reaction after learning about your background at HP was to wonder when you first felt the "entrepreneurial urge."

Seliger: l'm going to guess you're not talking about my paper route as a kid growing up in Mt. Vernon, New York.

NEJE: Well, if that's where it all started, why not? Seliger: No, I can't say the paper route did much for my entrepreneurial spirit. However, Hewlett Packard is a very innovative company where my interest in engineering and new product development could be combined to best advantage.

NEJE: But if HP is anything like the typical U.S. corporation, entrepreneurship is something you don't learn. Most managers are trained and enculturated to be risk averse.

Seliger: To a certain extent that's true, but HP managers actually thrived on thinking "out of the box." We were encouraged to solve business problems by being creative and original. I loved it.

NEJE: Yet you left corporate life and jumped off the proverbial cliff to become CEO of a new venture.

Seliger: It was one of the most difficult decisions I've ever made, but looking back on it now, it was one of the best. When I was working 60 hours a week at HP, I thought I was working hard. That experience only prepared me for the monster hours I'm putting in now. Starting up a company is an exercise in controlled manic behavior, yet so far, we've been doing very, very well.
NEJE: After 18 years and an accumulation of corporate perks, what prompted you to leave the corporate cocoon and become an entrepreneur?

Seliger: It certainly wasn't an impulsive decision on my part. With a bunch of corporate stock options and a company car, a pleasant and secure life style for my wife and children, the last thing I expected to do was to leave HP.

The events that led to my eventual decision to leave corporate life require some background information.

I had two different roles at HP. First, I was a staff principal architect working to make sure the five corporate divisions under the HP Medical Products Group banner developed harmonious products for clinical care use. As a corporation, HP had a history of sometimes not engineering products that were compatible with each other. Imagine buying a Sony television and then a Sony VCR and the two not working together. That was happening at HP and my job was to have the different functional teams in these five divisions work together to produce compatible systems. 1 had a lot of responsibility but no authority over these folks so it took a deft hand to negotiate my way through various agendas, egos, and conflicting business interests.

I had been asked as well to also serve as a manager and run a large product development team comprised of U.S. and German engineers. I was very aware that information flow was becoming more and more of a serious problem in health care. Breakthroughs in health care technology and the advent of the Internet held the promise for the medical community that it could break out of its isolation of "stand alone" information environments. Doctors were anxious to create new networks and applications where exchanging and sharing patient information literally around the world could be made easy, fast, and responsive to care giver needs

NEJE: And that's what you came up with? A way to integrate all this information even though they might be on different platforms?

Seliger: That's the purpose of Sentillion and the alliances we've made with key companies in the health care area like Microsoft, Eclipsys, GE Medical Systems, McKessonHBOC, Medscape, and Picis. We all are interested in creating a reliable standards-based, fully integrated experience for the caregiver. 
NEJE: That sounds terrific, but why didn't you just stay at HP and do the same things?

Seliger: Good question. Let's use an analogy. Let's say that an engineer at Ford came up with an important solution for improving gasoline mileage. Ford would presumably develop it, test it, and use it in the entire Ford line. Now imagine that Ford's competitors would also benefit from the technology. The problem is, they would need to license the technology from Ford, a competitor. However, how would the other carmakers feel? Quite possibly that they were getting licensed technology degraded or changed in several critical ways because Ford wanted to keep critical aspects of the gasoline technology for itself alone.

NEJE: That sounds reasonable, though, for Ford to want to do that. After all, their engineer developed the better fuel process.

Seliger: Good for Ford, perhaps, but it would have been a nonstarter for me. That is exactly the consideration I faced back in 1998. I could stay at HP and develop the needed software solutions for medical information integration, but its use and applications would have been limited to just HP products. Given the fierce competition among healthcare vendors, HP's competitors wouldn't have touched it. They wouldn't have trusted HP to give them the same quality product that HP would have access to.

NEJE: So you needed to cut your ties with the only corporate home you had ever known. Either that or move on to other products and drop the opportunity to develop this software.

Seliger: Exactly. The answer was to create a new company, separate from HP, but starting with technology spun out from HP. To do this meant that I had to leave HP and sever my ties with everyone I knew there except for a few fellow employees who left with me to start Sentillion. I knew I needed to set up an operation that was Swiss-like in its neutrality in the market. We could not be perceived as an extension or puppet of HP or else HP competitors would never consider using our products.

NEJE: Let's role-play for a moment. I'm your manager at HP. I learn you're interested in developing a particular type of software integration product for clinical care by spinning out a new company. Why would I let you do that? It would mean losing you, your experience, your know-how, and future success at the company. No way.

Seliger: Sure I thought of that. I have to admit also to thinking that maybe this whole idea was crazy. That I was crazy to even consider doing something like this. Leave HP? Become entrepreneurial and have to raise millions from venture capitalists to get the organization off the ground? See even less of my family? For what? For the risk that maybe I could make a go of it? At the time I was more concerned with failure than with success

\section{NEJE: What if Sentillion does fail?}

Seliger: We won't fail. I came to realize that the only real risk that I face is an emotional one. It's that I could put my heart and soul into this new venture and that after years of effort and dedication my dream didn't pan out. But it's no longer fear that I feel. Rather, it's the passion to see Sentillion successful that explains the 100-hour plus weeks.

NEJE: Let's go back to the role-play. I'm your manager and there's no way that you're leaving HP to chase your dreams with my blessings.

Seliger: Before approaching anyone, I decided to take a week's vacation so I could find inspiration in the company of my family and think about what to do in a relaxed atmosphere.

\section{NEJE: And?}

Seliger: Well ... nothing. No inspiration came. We had a great time on vacation but nothing came to me. I went back to work conflicted and really unsure of what to do next.

NEJE: So, your next step was ... ?

Seliger: I felt I needed to talk this whole concept out with several people who could be effective mentors for me. Two were inside HP and the other was a consultant I had hired to work with me on addressing the organizational challenges of achieving cooperation and alignment in product development across different business units. The consultant is a professor at Northeastern University and he thought the concept of integrating health care records made a lot of sense. He told me l'd be crazy not to seize the opportunity and run with it.

Then I went to my manager. He was the second person I had identified who could be helpful.

NEJE: Wasn't that a big risk? After all, it would suggest you might want to leave the organization and that could have impeded future promotions.

Seliger: Actually, no, not with my boss, who was the chief technology officer of the Medical Products Division at the time. One day in his office, I just floated the concept and gave him some broad brushstrokes of what I thought I could do. He told me it was the best idea he'd heard in years and then asked me what he could do to help me along.

NEJE: To help? Sorry for being a little incredulous, but why would your manager volunteer to help you when it would mean losing you at HP? 
Seliger: The culture at HP is different from many other corporations. The company encourages and rewards innovation. Yes, I was proposing to leave the company, but in a way that would help them-and others-in the healthcare information technology arena.

The third person I shared my idea with was my manager's manager, the vice president responsible for all of Medical Products Group. After I had taken two minutes to explain my idea to her, she interrupted and said, "Rob, the idea is fantastic. This is what you'll need to do to make it happen." I wrote down notes furiously for the next hour. It was the beginning of my education on bootstrapping our operation.

NEJE: Did the company sponsor you in any way? Open up doors, supply seed money and office space? Seliger: No, HP didn't even get a seat on the board of directors. I had to make a clean break as I explained earlier. However, I did have to get legal clearance and a release on certain intellectual property and software from the company before I could get Sentillion off the ground. That process took eight months. Eight months! That's as good an example as any of how corporate bureaucracy can wear you down and inhibit risk-taking. But I finally got the releases and said good-bye to HP in December 1998.

\section{NEJE: What did your wife say about all this?}

Seliger: She had more confidence in my abilities most days than I did. Elaine would say, "What do you really have to lose? You'll learn a heck of a lot and have fun at the same time. It's a no-brainer."

\section{NEJE: How did you come up with the name "Sentillion?"}

Seliger: I played around with different sounding technical names and entered all of them into Internet search engines to see if they were already taken. Finally 1 created Sentillion by changing the "c" to an " $\mathrm{s}$ " from the word "centillion," which is a one followed by 303 zeroes. We wanted a name that sounded interesting, did not align us with any particular industry (which is important as we diversify beyond healthcare), and that did not include dot-com. Even back in 1998 we did not think that just adding dotcom to our name would bring any value.

NEJE: So far, all well and good. You have the idea, the willingness to work hard, the blessings of the good folks at HP, but what did you know about raising venture capital?

Seliger: What I didn't know, and that was considerable, I learned quickly. First came the business plan that I put together with John Douglas, the cofounder of Sentillion who's in charge of marketing, and like me, a former employee of HP. We read every article we could get our hands on about raising venture capital, but soon realized the best way to learn was by doing, not reading. It's like learning to swing a baseball bat. You can read all you want about the proper form, the best position for your legs and how to hold your hands, but finally you have to swing the bat to get the hang of it.

The other thing we learned right away is how important networking can be. If you know people who know people who know other people who are venture capitalists, it can open up doors much faster than cold calling. Fortunately, there were people within HP who had that kind of networking ability and opened up doors for us immediately that could have taken us months and months on our own.

We still had lots of homework to do. Venture capitalists may get a dozen new proposals a day. How do you rise above the crowd? One way is to research the funds and ask some key questions. What are their interests? What is the fund's past investment record? What is their present portfolio? What do we know and/or need to know about the individual fund managers?

Our biggest challenge was in figuring out the best way to show and demonstrate our product since what we were developing was not an end application you could see on your computer screen, but a "behind-the-scenes" solution to pulling applications together. A similar product did not exist so we needed a solution as to how to explain quickly and simply what we were all about.

We prepared slides and a demo and went on the road. We soon realized, however, we had made a big mistake. In presentations, we would start to explain what Sentillion was all about and found to our consternation that often our listeners had misinterpreted what was said. They had come to the wrong conclusion about what we were attempting to do in the marketplace before we even got the chance to demo the idea. What followed was inefficient and took a lot of time. It was "no, we didn't mean that," and "no, this is what we're talking about."

The solution was to move the demo up to the beginning of the presentation so folks could get right on track with us from the start. That and dozens of other efforts at fine-tuning the presentation eventually paid off when we met with a San Francisco-based venture group where the folks were very receptive. They wouldn't commit to us without a second fund signing on as well, but it was a solid first start for us. Our contact there suggested we change legal counsel to a California law firm whose specialty was legal counsel to business start-ups. It turned out to be a great move since the law firm immediately introduced us to another venture capital firm who was equally receptive. Even more interestingly, as word got out, a firm approached us and asked to participate. We closed our first round with three firms. 
NEJE: You got the funding you needed and set up shop. That must have been very fulfilling.

Seliger: It was, but we had no time to celebrate. Sentillion was started in my home, as one of the lessons we learned was how long it can take to find affordable office space. 1 used my upstairs as my home office, the development team was holed-up in the dining room, and the IT folks ran the servers from my basement. We managed like that for six months but by then we had a staff of 12 and in June 1999, moved out to an office location nearby.

A year later, in August 2000, we moved again to larger offices in the same building and finished last year with a staff of 38. The average age around here is 40 ; this is not a- "twenty-something" start-up. John and I decided at the outset to go after experienced people rather than those who might have to learn on the job. It cost us more in starting salaries but each person we brought on knew how to hit the ground running and that ultimately meant having to hire fewer staff.

We're not profitable yet, and we are now in the process of raising an expansion round of venture capital funding, but we will soon break even as we establish Sentillion in a big way in the healthcare IT market.

\section{NEJE: Do you consider yourself a visionary?}

Seliger: Some people have described me that way, but I don't agree with them. Bill Gates fits that description. So does Steve Jobs. I'm just someone who wanted to bring an idea to life. That's my passion.

One of my biggest accomplishments is having companies that are arch rivals nevertheless conduct business with Sentillion. They're willing to work with Sentillion because they like our concept and want to be part of building better healthcare IT solutions. Remember, doing this was the reason I conceived of Sentillion in the first place.

\section{NEJE: What have you learned about yourself in the process?}

Seliger: I never thought of myself as an entrepreneur before Sentillion because I never thought I would enjoy dealing with ambiguity. An entrepreneur has to deal with ambiguity all the time. It seemed contradictory to my nature. Educated and trained as an engineer, $I$ always wanted to arrive at a precise answer in an environment that valued exactness and certainty.

Well, here at Sentillion, I've had to develop a deep respect for all the things I don't know and may never know. l've had to learn how to adjust and make sharp turns quickly in how I think and process data. But the biggest kick is changing ambiguity to certainty. As long as I am able to do that, step by step, then I am happy.

\section{NEJE: What about the risks? There's still the risk you could fail.}

Seliger: True, but to be honest, it's our customers who are taking the risks. Their belief in what we're doing and how we're doing it means they are putting their future on the line. Further, I didn't have to mortgage my home to go into this venture; we're using other people's money. My personal downside risk in a fiscal sense is pretty minimal from that standpoint. Respecting the risk that our customers and investors are taking is one of the reasons that we forge deep, responsive, and trusting relationships with these people.

In terms of managing the formidable challenges that Sentillion faces, I see this effort as if I were a mountaineer who faced the biggest climb of my life. I don't have to climb all the way to the top in one go. I just have to climb the mountain in sections, getting to one level and reaching stability, then moving on to the next level. Each level is literalIy, for us, making our next quarterly fiscal numbers, releasing a new product, or forging a new business relationship. Then we climb on to the next plateau.

Around June 2000 , we reached a very personal level on that mountain for me. I came to believe it was not a question of "if" for Sentillion, but "when." That was a profound change in my confidence and was the moment 1 knew that only good things could happen going forward.

\section{NEJE: Did you take time out to reward yourself? Have you celebrated reaching any of the important levels up the mountain with a party or dinner out?}

Seliger: John and I have promised ourselves a dinner out with our wives for the past two years, come to think of it.

\section{NEJE: Just promised?}

Seliger: Well, to tell you the truth, we haven't had the time to do it yet. But we will someday. We just have to find the time. I have to admit we haven't stopped to "smell the roses" enough along the way because there's always 20 new things to do after we accomplish something big. However, we've only been in existence for 26 months. There'll be time down the road to relax and reflect on all this. 